\title{
Perspective \\ From Pathophysiological Hypotheses to Case-Control Study Design: Resistance from Antibiotic Exposure in Community-Onset Infections
}

\author{
Salam Abbara ${ }^{1,2} \mathbb{D}$, Didier Guillemot ${ }^{1,2,3}$, Christian Brun-Buisson $1,2,+$ and Laurence Watier $1,2, *,+\mathbb{D}$ \\ 1 Anti-Infective Evasion and Pharmacoepidemiology Team, Inserm, UVSQ, University Paris-Saclay, CESP, \\ 78180 Montigny-Le-Bretonneux, France; salam.abbara@gmail.com (S.A.); didier.guillemot@pasteur.fr (D.G.); \\ chris.brunb@gmail.com (C.B.-B.) \\ 2 Institut Pasteur, Epidemiology and Modelling of Antibiotic Evasion (EMAE), 75015 Paris, France \\ 3 Public Health, Medical Information, Clinical Research, AP-HP, University Paris Saclay, \\ 94270 Le Kremlin-Bicêtre, France \\ * Correspondence: laurence.watier@inserm.fr; Tel.: +33-1-45-68-80-00 \\ + These authors contributed equally to this work.
}

Citation: Abbara, S.; Guillemot, D.; Brun-Buisson, C.; Watier, L. From Pathophysiological Hypotheses to Case-Control Study Design:

Resistance from Antibiotic Exposure in Community-Onset Infections. Antibiotics 2022, 11, 201. https:// doi.org/10.3390/antibiotics11020201

Academic Editor: Roman Kozlov

Received: 5 January 2022

Accepted: 2 February 2022

Published: 4 February 2022

Publisher's Note: MDPI stays neutral with regard to jurisdictional claims in published maps and institutional affiliations.

Copyright: (c) 2022 by the authors. Licensee MDPI, Basel, Switzerland. This article is an open access article distributed under the terms and conditions of the Creative Commons Attribution (CC BY) license (https:// creativecommons.org/licenses/by/ $4.0 /)$.

\begin{abstract}
Antimicrobial resistance is a global public health concern, at least partly due to the misuse of antibiotics. The increasing prevalence of antibiotic-resistant infections in the community has shifted at-risk populations into the general population. Numerous case-control studies attempt to better understand the link between antibiotic use and antibiotic-resistant community-onset infections. We review the designs of such studies, focusing on community-onset bloodstream and urinary tract infections. We highlight their methodological heterogeneity in the key points related to the antibiotic exposure, the population and design. We show the impact of this heterogeneity on study results, through the example of extended-spectrum $\beta$-lactamases producing Enterobacteriaceae. Finally, we emphasize the need for the greater standardization of such studies and discuss how the definition of a pathophysiological hypothesis specific to the bacteria-resistance pair studied is an important prerequisite to clarify the design of future studies.
\end{abstract}

Keywords: drug resistance; microbial; case-control studies; risk factors; anti-bacterial agents; public health

\section{Introduction}

Antimicrobial resistance (AMR) has emerged as a major public health threat with a high human and financial cost [1]. An abundant literature documents the link between antibiotic use, misuse, and the emergence of resistance (whether colonization or infection with resistant bacteria) [2]. Accordingly, appropriate antimicrobial use is at the core of all programs to fight AMR [1,3,4].

Over the last decades, resistance has widely spread in the community, shifting at-risk populations outside of hospitals. Salient examples are the community spread of extendedspectrum $\beta$-lactamases producing Enterobacteriaceae (ESBL-pE), or of USA300 methicillinresistant Staphylococcus aureus (MRSA) [5,6]. Olesen et al. showed that population-wide resistance was more linked with broadly distributed antibiotic use, rather than with the intensity of use [7]. Thus, to better design control programs fighting AMR, it is important to clarify the link between antibiotic exposure and resistance in the community, where most antibiotic prescriptions occur [8]. This link should be evaluated depending on the bacteria-resistance pair. Indeed, for the same bacterial strain, various mechanisms interact at the individual and population level, leading to the emergence of a particular resistance in a given host [9]. Moreover, it is becoming increasingly clear that what is established for one bacterial species cannot be extrapolated to another, or even to different phylotypes within the same bacterial species [9]. 
Numerous epidemiological studies, mainly with a case-control design (comparing patients with resistant bacteria to patients with susceptible bacteria), have analyzed the link between antibiotic exposure and bacterial resistance, with various conclusions. Their methodological challenges-particularly the choice of the source population, control groups, and the measurement of antibiotic exposure-have already been discussed [10-14]. Definitions of colonization and infection are variable, and some studies combined them [15]. These limitations impact the interpretation of the study results and their integration into a global scheme specific to the bacteria-resistance pair of interest. Overall, it appears necessary to move towards the greater standardization of case-control studies looking at the link between antibiotic exposure and resistant infections. This standardization is even more important when studying the community context, as the study results may have an impact on the general population.

In this paper, we emphasize the key points and challenges involved in the construction of case-control studies studying the link between antibiotic exposure and resistant community-onset infections. We also discuss the importance of defining a pathophysiological hypothesis specific to the bacteria-resistance pair studied to clarify the design and interpretation of future studies. To this end, we review case-control studies evaluating the impact of antibiotic exposure on the occurrence of antibiotic-resistant community-onset (CO) urinary tract (UTI) or bloodstream (BSI) infections. In selected studies, we show the heterogeneity in the key points related to the risk factor of interest, the population and design: antibiotic exposure, cases, controls, and case-control design. We discuss the impact of this heterogeneity on the study results, focusing on ESBL-pE, often studied because of their rapid spread in the community, their propensity to colonize the human microbiota, and their morbidity and mortality [5]. Finally, we explain how to construct the pathophysiological hypothesis related to the bacteria-resistance pair studied, and how this translates when building a case-control study.

\section{Studies' Epidemiological Key Points: Challenges, Findings and Limitations}

\subsection{Risk Factor: Antibiotic Exposure}

Four points need to be specified when studying antibiotic exposure [10]: 1 . the choice and classification of antibiotics (by drug, class, or spectrum of activity); 2 . the way antibiotic exposure was collected; 3 . the selected window of exposure (period prior to patient inclusion, during which previous antibiotic exposure is assessed); 4 . whether antibiotic exposure is considered with or without other criteria (quantification through defined daily doses, length of treatment, etc.).

\subsubsection{Classification}

The classification of antibiotics was very heterogeneous among selected studies (Tables S1 and S2) [16-62]. Overall antibiotic exposure (i.e., without specifying a drug or class) was analyzed as a risk factor in $77 \%(36 / 47)$ of studies, while cephalosporins, (fluoro)quinolones, and penicillins were frequently individualized, with various subclassifications. Note that studying antibiotics as a function of the drug, or globally, are complementary approaches: the first evaluates the link between (a) particular (class of) antibiotic(s) and the development of resistance for a bacteria-resistance pair; the second considers the overall impact of various antibiotic exposures on the process leading to resistance. Among all studies, 30\% (14/47) individualized 5+ different (classes of) antibiotics. Moreover, 9\% (4/47) individualized 10+ of them, without mentioning any method of adjustment to avoid alpha risk inflation due to multiple comparisons [31,41,52,58]. Anti-anaerobic antibiotics were individualized in 26\% (12/47) of studies ("anti-anaerobic", no. $=1$; metronidazole, no. $=2$; penicillins with $\beta$-lactamase inhibitors, no. =9). Given the role of anaerobes as a barrier flora $[63,64]$, isolating anti-anaerobic antibiotics as a distinct group in future studies should be informative. 


\subsubsection{Collection of Antibiotic Exposure}

The way in which antibiotic exposure was collected was not specified in 13\% (6/47) of studies. More than half of the studies (27/47) assessed antibiotic exposure through medical records. This may induce a bias as the exposure to antibiotics is not systematically and homogeneously collected and traced in medical records. Patient interviews, which are subject to recall bias, were used in 13\% (6/47) of studies. The assessment of delivered antibiotics in pharmacy databases was conducted in $9 \%(4 / 47)$ of studies. Because data reported by community pharmacies often relate to the dispensing of antibiotics, they may not reflect the actual consumption by patients.

\subsubsection{Window of Exposure}

Among the 47 studies analyzed, 2\% (1/47) did not define the window of exposure, and others used a window of exposure varying between 15 days and 1 year. Half of the studies (24/47) limited the window of exposure to 3 months. Only $21 \%$ of studies $(10 / 47)$ considered windows of exposure longer than 3 months. Note that selecting the window of exposure is critical, particularly when addressing bacteria associated with persistent carriage. For instance, the duration of ESBL-pE carriage in the intestine may differ substantially according to the context of acquisition and population $[65,66]$. It could exceed 12 months in some subpopulations, such as critically ill patients or those exposed to antibiotics [66]. Thus, defining the window of exposure should be conducted according to the available information on the dynamics of the acquisition and loss of the studied resistant bacteria, and on the hypothetical source population. Another critical point when studying community-onset infections is to exclude antibiotics administered before inclusion for the patient's current infection from prior antibiotic exposure. To this end, the window of exposure should exclude recent exposure to antibiotics. One study [33] explicitly mentioned excluding antibiotic exposure in the previous month from analysis. Defining the appropriate time limit between treatment of the infectious episode and prior antibiotic exposure can be difficult and depends on the studied infection and study setting. A sensitivity analysis testing several exposure windows could be considered, to test multiple hypotheses and add quantitative evidence to the influence of time from prescription to the occurrence of an antibiotic-resistant infection [57].

\subsubsection{Quantification of Antibiotic Exposure}

Almost all reviewed studies evaluated prior exposure to antimicrobials (exposed vs. non-exposed), regardless of other criteria. One study defined antibiotic exposure as at least one standard dose in $>24 \mathrm{~h}$ [37], a second defined it as the use of any antimicrobial agent for $\geq 3$ days [28], and a third studied various doses and durations of treatment [57].

\subsection{Populations and Design}

\subsubsection{Cases: Community-Onset Infections}

$\mathrm{CO}$ infections were commonly defined by their occurrence within the first $48 \mathrm{~h}$ of hospitalization (9/11 studies for CO-BSI, $3 / 9$ studies for CO-UTI), sometimes excluding patients transferred from other hospitals or hospitalized within few weeks (Table S3) [67]. Other definitions considered outpatients, patients presenting at the emergency department (ED), or patients referred by their general practitioner. Another level of complexity is added when trying to define truly CA-infections, i.e., $\mathrm{CO}$-infections that are not healthcare associated (HCA). While considering "CA-UTI", 1/21 study did not define them. In other studies, the lability between $\mathrm{CO}$ and CA-infections was strong, as only 9/21 studies of CA-UTI excluded patients with exposure to healthcare.

The value of individualizing HCA-infections could be questioned. Its main clinical interest would be an increased risk of drug-resistant pathogens and mortality in HCAinfections, which may justify aggressive diagnostic and treatment measures [67]. However, taking the example of HCA-pneumonia (HCAP), the risk of AMR and adverse outcome attributable to HCAP appears to have been overestimated and may have resulted in 
over-treatment $[68,69]$. Yet, from an epidemiological point of view, individualizing HCAinfections seems useful. A study by Lin et al. identified antibiotic exposure as a risk factor for ESBL-pE BSI, but only in CO-BSI and not in CA-BSI [23]. Thus, repeating analyses done on patients with $\mathrm{CO}$-infections in the subcategory of patients with CA-infections could better define the populations at risk.

The definitions of HCA-infections are diverse, and have been challenged for some infections, including pneumonia and BSI $[67,69,70]$. When prior exposure to healthcare was analyzed as a risk factor in the studies reviewed (11/11 in CO-BSI, 1/4 in CA-BSI, 17/21 in CA-UTI, 9/9 in CO-UTI), various definitions were considered: Friedman's criteria [67], history of hospitalization or surgery or invasive urinary tract procedure (with various periods prior to admission), or residency in a nursing home or long-term care facility. If reaching a consensus on an operational definition of HCA infections seems difficult, case-control studies of CO-infections should at least clearly specify the definitions used for $\mathrm{CO}, \mathrm{CA}$ and HCA-infections, and exclude patients with healthcare exposure from the CA group.

\subsubsection{Controls}

In case-control studies, the definition of controls is a crucial step, depending on the specific question addressed. Most case-control designs define the control group as patients infected with a susceptible bacterium (to the studied antibiotic) [10,11]. This identifies the differential impact of antibiotic exposure on infection with the susceptible or resistant bacteria. For clinicians, such studies help determine the optimal empiric treatment for a patient with a presumed infection to the studied bacteria (e.g., to determine whether carbapenem treatment is warranted to cover ESBL-pE strains when selecting empiric therapy for UTI) $[10,14]$.

To study community-acquired infections, it seems important to include a control group that approaches the uninfected source population. Such studies give valuable information on the impact of antibiotic exposure on the overall process leading individuals from the community to ultimately become infected. However, including uninfected patients can be very challenging, especially when it comes to identifying a representative sample within the community [10-13]. Moreover, the controls should have the same characteristics as those chosen by the authors to define community-acquired infections. Notably, the same criteria related to exposure to care (e.g., hospitalization in the previous week, recent surgery, or any other criteria) used for excluding cases should be applied to controls. Finally, depending on the studied pathogen and on the scientific question, this group could be the general population (if the pathogen is commensal), or uncolonized individuals from the general population for non-commensal species.

\section{Patients Infected with Susceptible Bacteria}

Two thirds of the retained studies addressed ESBL-pE CO or CA-UTI or BSI (29/47; BSI, no. = 8; UTI, no. =21). Focusing on the 23 studies including a multivariate analysis $(B S I$, no. = 7, Table S4; UTI, no. = 16, Table S5), all included a control group having nonESBL-pE infections [16,18-22,26,33-48]. Although they are usually considered risk factors for ESBL-pE, global exposure to antibiotics (median, min-max univariate odds ratio (OR): 6.3, 3.2-10.7 in BSI; 4.3, 2.0-10.1 in UTI), particularly cephalosporins (median, min-max OR: 6.07, 4.4-13.4 in BSI; 3.5, 1.4-17.1 in UTI) and quinolones (median, min-max OR: 6.4, 3.0-7.0 in BSI; 2.4, 0.9-5.8 in UTI), were risk factors in the multivariate analysis in only half of the studies that considered them (BSI, 3/4, 2/4, and 2/4 studies; UTI, 6/11, 5/10, and 4/10 studies, respectively). In UTI, exposure to other antibiotics, such as penicillin, macrolide or nitrofurantoin, were risk factors in a minority of studies $(2 / 8,1 / 2,1 / 4$, respectively). The exposure windows were variable, most being $\leq 3$ months, precluding conclusions on the impact of antibiotics taken previously. In addition to differences in population characteristics, size, and setting, heterogeneity in the definition of exposure and cases may have contributed to these variable results. A small number of studies focused 
on CA-infections, with small numbers of patients and a wide methodological variability, which makes it impossible to assess if there are specificities in CA-infections compared to CO-infections.

\section{Uninfected Hosts}

No study with ESBL-pE BSI used uninfected controls. Only one study on ESBL-pE COUTI considered two control groups among which uninfected patients, randomly selected among residents from the same geographical are as cases [33].

\subsubsection{Designs}

Most of the studies used a case-control design, except four studies that used a casecontrol(case)-control design. This design includes a third group of patients, to be considered as a second group of cases (if compared to the control group), or a second group of controls (if compared to the case group) [14]. In three studies, this third group included patients with sepsis [16], bacteremia of all causes [18], or infection with a bacterium that was different from the two other groups [35]. Only one study used a case-control-control design with both types of controls discussed previously, among which uninfected patients [33]. Such a design helps to identify whether antibiotic administration in individuals from the community selectively impacts the risk of developing a resistant infection, or the risk of having an infection, whether it is susceptible or resistant [14]. Indeed, comparing uninfected patients with both other groups allows to individualize the impact of antibiotic exposure on the occurrence of an infection to a resistant or a susceptible bacterium, independently. As such, the study by Søgaard et al. suggests that in an uninfected individual from the general population, prior exposure to broad-spectrum antibiotics, mecillinam, sulfamethizole and trimethoprim, could increase the risk of UTI to a non-ESBL or ESBL-pE. On the other hand, exposure to macrolides and nitrofurantoin could selectively increase the risk of ESBL-pE UTI [33].

\section{Pathophysiological Hypotheses}

To move towards greater standardization in future studies, we propose to construct and interpret them within a pathophysiological (i.e., causal) hypothesis specific to the bacteria-resistance pair of interest (Table 1). This hypothesis would detail the steps leading an uncolonized host from the community to present with an antibiotic-resistant infection. Authors could then embed their study within those steps. The hypothesis can be formulated at a macro-level (which can be embodied by different groups of patients, to help to design case-control studies), or a micro-level (considering intra-host and host-microbiota interactions and dynamics, adapted for other study designs). This strategy would help to design the study in such a way as to provide the most correct answer to the specific question addressed, while allowing the results to be interwoven with other study results. Ultimately, this would allow for a global view of the role of antibiotics at each step leading to an antibiotic-resistant infection, for a specific bacteria-resistance pair. It also allows the identification of transitions for which the impact of antibiotic exposure has not been studied, prompting additional studies.

Table 1. Key points to design case-control studies evaluating antibiotic exposure as a risk factor of resistance in community-onset infections.

- Identify the bacteria-resistance pair of interest.

- $\quad$ Define the pathophysiological hypothesis, clarifying the hypothetical uncolonized/uninfected source population and steps leading to infection.

- Determine the step(s) and the specific question that the study wants to address.

- Choose the control and case groups accordingly. 


\subsection{Construction of the Pathophysiological Hypotheses}

The pathophysiological hypothesis would detail the hypothetical causal chain leading an uninfected host to present an infection by the resistant bacteria. In order for an infection to occur in an individual, it is generally required that this individual has been previously colonized by this bacterium [64]. Whether the resistant bacteria can be acquired directly (as with MRSA), or whether it is generally necessary to go through a colonization stage by a susceptible strain secondarily acquiring resistance (as could be hypothesized for Pseudomonas aeruginosa), depends on the species and the resistance. Subsequently, infection is differentiated from colonization by the presence of clinical signs signaling the transition from asymptomatic carriage to infection [15].

Depending on the bacteria-resistance pair, a macro-level pathophysiological hypothesis could include four states, all of which could be embodied through specific patient groups: (1) no carriage of the pathogenic bacteria; (2) carriage of the susceptible pathogenic bacteria (e.g., colonization with a new phylotype of Escherichia coli, transient colonization by Streptococcus pneumoniae or S. aureus, transient or persistent colonization with Enterobacter cloacae, Serratia spp., Klebsiella spp.); (3) carriage of the resistant pathogenic bacteria (whether by mutation of a susceptible bacteria, acquisition from another host, or lateral gene transfer); (4) infection with the resistant pathogenic bacteria $[9,15,71]$. When designing a case-control study, clarifying the state(s) for which risk factors are being sought helps to define the most appropriate case and control groups (as proposed in Table 2).

Table 2. Selecting the case and control groups according to the specific question.

\begin{tabular}{lll}
\hline \multicolumn{1}{c}{ Control Group } & \multicolumn{1}{c}{ Case Group } & \multicolumn{1}{c}{ Question Addressed } \\
\hline Uncolonized hosts & $\begin{array}{l}\text { Hosts colonized with a given } \\
\text { species }\end{array}$ & $\begin{array}{l}\text { Assess the impact of antibiotic exposure on the risk of } \\
\text { colonization. }\end{array}$ \\
\hline $\begin{array}{l}\text { Hosts colonized with the susceptible } \\
\text { bacteria }\end{array}$ & $\begin{array}{l}\text { Hosts colonized with the } \\
\text { resistant bacteria }\end{array}$ & $\begin{array}{l}\text { Assess the impact of antibiotic exposure on the } \\
\text { apparition of a resistant strain within the colonizing } \\
\text { susceptible strain. }\end{array}$ \\
\hline Hosts colonized with a bacterial strain & $\begin{array}{l}\text { Hosts infected with the same } \\
\text { bacterial strain }\end{array}$ & $\begin{array}{l}\text { Assess the impact of antibiotic exposure on the } \\
\text { progression from colonization to infection. }\end{array}$ \\
\hline Uninfected hosts & $\begin{array}{l}\text { Hosts infected with the } \\
\text { resistant bacteria }\end{array}$ & $\begin{array}{l}\text { Assess the overall impact of antibiotic exposure on the } \\
\text { process leading an uninfected host to present an } \\
\text { infection to the studied resistant bacteria. }\end{array}$ \\
\hline $\begin{array}{l}\text { Control group 1: uninfected hosts } \\
\text { with the susceptible bacteria }\end{array}$ & $\begin{array}{l}\text { Hosts infected with the } \\
\text { resistant bacteria }\end{array}$ & $\begin{array}{l}\text { Assess whether antibiotic exposure selectively impacts } \\
\text { the risk of developing a resistant infection, or the risk of } \\
\text { having an infection, whether it is susceptible or resistant. }\end{array}$ \\
\hline $\begin{array}{l}\text { Hosts infected with the susceptible } \\
\text { bacteria }\end{array}$ & $\begin{array}{l}\text { Hosts infected with the } \\
\text { resistant bacteria }\end{array}$ & $\begin{array}{l}\text { Determine the most appropriate empiric treatment for a } \\
\text { patient with a presumed infection to the studied bacteria. } \\
\text { Assess the differential impact of antibiotic exposure on } \\
\text { the processes leading a host to present with an antibiotic } \\
\text { susceptible or resistant infection. }\end{array}$ \\
\hline
\end{tabular}

( 1 The control group 2 could be considered a case group 2, depending on the groups statistically compared by the study.

\subsection{An Example: ESBL-Producing E.coli ST131 CO-Infections}

To illustrate the interplay between the macro-level pathophysiological hypothesis and the design of case-control studies, we will focus on a specific bacteria-resistance pair, ESBL-producing (ESBL-p) E. coli sequence type 131 (ST131). ESBL-p E. coli ST131 is a pandemic multidrug resistant (MDR) strain that is expanding rapidly in the community [72]. To study risk factors for infection with ESBL-p E. coli ST131, a 4-step pathophysiological hypothesis beginning from the general population as the source population [72] could be proposed (Figure 1): (1) absence of ST131 E. coli carriage; (2) carriage of ST131 E. coli through individual cross-transmission, with transient colonization; (3) carriage of ESBL-p 
E. coli ST131 (after acquisition of ESBL gene-containing plasmids by horizontal transmission); (4) infection with ESBL-p E. coli ST131, for instance via intestinal translocation [72]. Understanding and weighing the potential role of antibiotics in the transition from one step to the next requires a specific design for each transition.
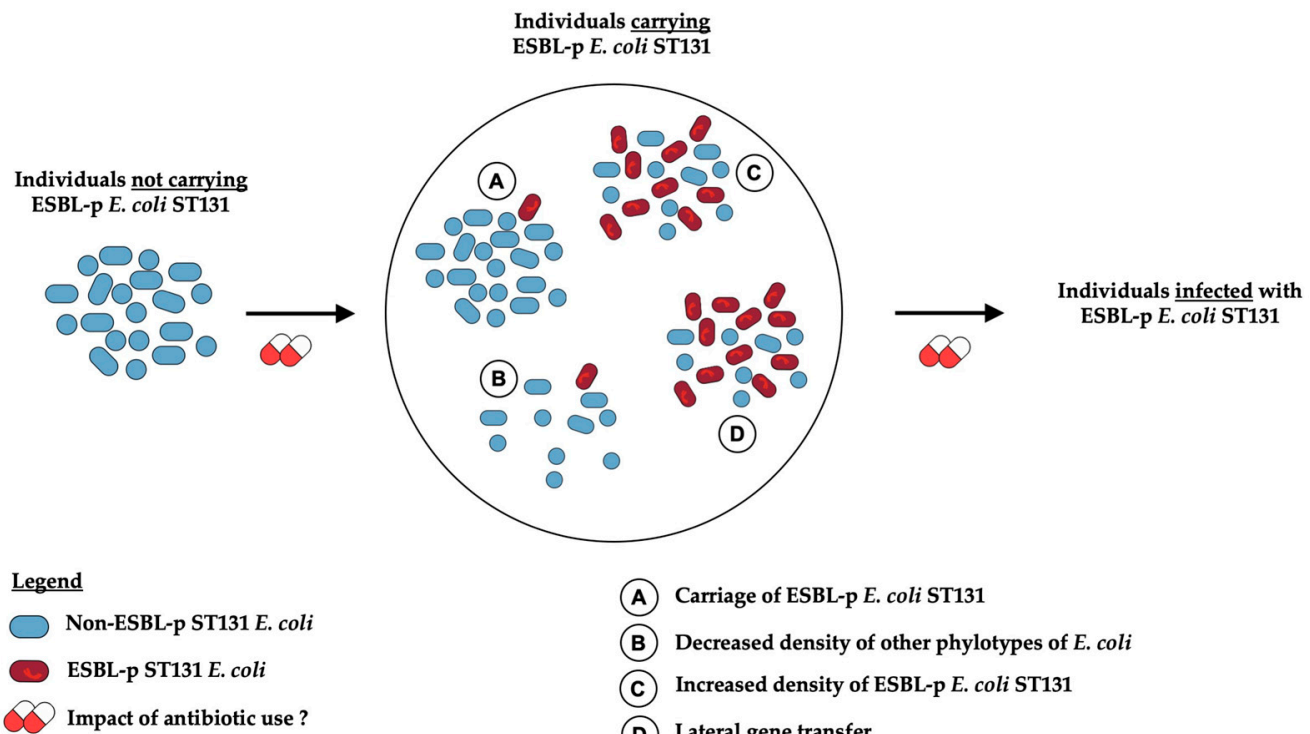
(A) Carriage of ESBL-p E. coli ST131
(B) Decreased density of other phylotypes of $E$. coli
(C) Increased density of ESBL-p E. coli ST131
(D) Lateral gene transfer

Figure 1. Pathophysiological hypothesis to study antibiotic exposure as a risk factor for infection with ESBL-producing Escherichia coli ST131.

Morales Barroso et al. studied the role of antibiotics in the acquisition of ST131 E. coli (irrespective of ESBL production) in an uninfected host (step 1 to 2). They compared ST131 colonized and non-ST131 colonized household members of index community patients with E. coli ST131 infection and did not identify antibiotic exposure as a risk factor [73]. To our knowledge, no case-control study has used hosts carrying non-ESBL-p ST131 E. coli as controls, and ESBL-p E. coli ST131 as cases (step 2 to 3).

To evaluate the impact of antibiotic exposure in the transition from colonization to infection with ESBL-p E. coli ST131 (step 3 to 4), an optimal study design would include cases infected with ESBL-p E. coli ST131, and uninfected controls carrying ESBL-p E. coli ST131. To our knowledge, such a study has not been published. More generally, if antibiotic exposure has been shown to impact the risk of colonization to some MDR Enterobacteriaceae, its role in the progression from colonization to infection is partly understood [64]. Studies on this topic usually focus on hospitalized patients, especially the ICU setting, where colonization with MDR bacteria is often assessed [74]. To better address this question, it is important to design dedicated community-based studies with colonized individuals as controls and infected individuals as cases [75-78].

Some studies compared cases with ST131 and controls with non-ST131 ESBL-p E. coli infections $[79,80]$. This design specifically examines the impact of antibiotic exposure on the risk of developing an infection due to the ST131 clone, among patients who would develop ESBL-p E. coli infections.

It is notable that, while case-control studies evaluate risk factors involved in the transition from a step to another of the pathophysiological hypothesis, they do not discriminate the exact intra-host and host-microbiota mechanisms and dynamics involving the antibiotic in this transition, which are better approached through mathematical models and require microbiome analysis $[10,81,82]$. In the example discussed above, a micro-level pathophysiological hypothesis could involve further steps between asymptomatic carriage and infection with ESBL-p E. coli ST131 (Figure 1): (1) depletion in other phylotypes of E. coli in the host microbiota [64]; (2) increase in lateral gene transfer of the ESBL gene within or between bacterial species [81]; (3) increase in density of ESBL-p E. coli ST131 among the 
host's flora [64] (which could be important for infections such as BSI [63]), with a loss of bacterial diversity. All these steps could be happening within the host microbiota of subjects carrying ESBL-p E. coli ST131 and be influenced by the selective pressure of antibiotics.

\section{Materials and Methods}

We reviewed published case-control studies examining antibiotic exposure as a risk factor of resistance in CO-BSI (no. = 15) or UTI (no. = 32) (Table S1; Figure 2). MEDLINE was searched through PubMed until June 2020, with no language restriction or publication date limit, using MESH terms. The MESH term "Community-acquired infections" retrieved studies focusing on both community-acquired (CA) and community-onset (CO) infections. Titles and abstracts were screened to exclude those unrelated to the topic at hand. The remaining articles were assessed for eligibility. The reference lists of these articles were also searched for relevant titles. Only full-text articles were included. Full-text articles written in a language other than English or French were translated prior to analysis.

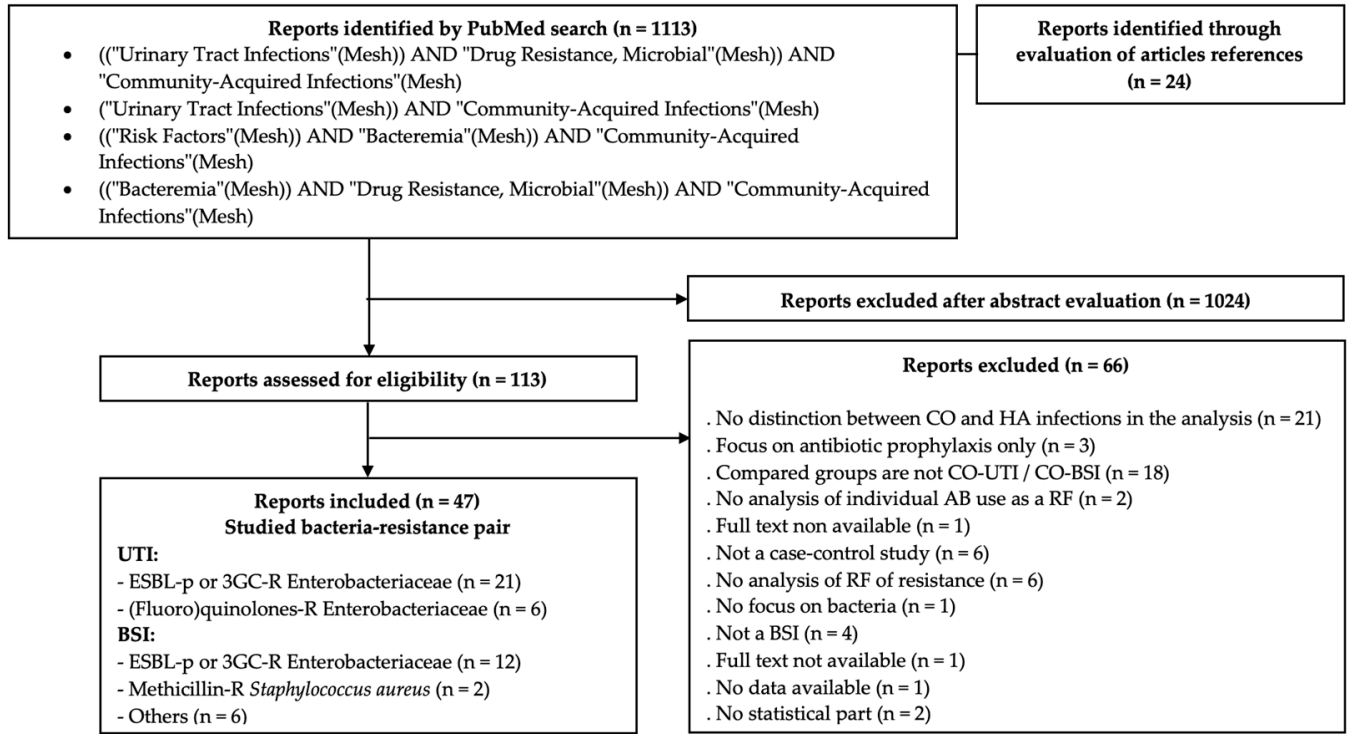

Figure 2. Flowchart of the selection process of case-control studies assessing the risk factors of resistance in bloodstream and urinary tract infections. Abbreviations: 3GC $=$ third generation cephalosporins; $\mathrm{AB}=$ antibiotic; $\mathrm{BSI}=$ bloodstream infections; $\mathrm{CO}=$ community-onset; ESBL- $\mathrm{p}=$ Extended-Spectrum $\beta$-Lactamase producing; HA = hospital acquired; $\mathrm{R}=$ resistant; $\mathrm{RF}=$ risk factor; $\mathrm{UTI}=$ urinary tract infections

\section{Conclusions}

The increasing prevalence of antibiotic-resistant infections in the community, where most antibiotics are prescribed, makes it essential to clarify the link between antibiotic exposure in the community and the development of antibiotic-resistant bacterial infections. To this end, we emphasize the need to standardize future studies addressing this link. Indeed, those already published present a great heterogeneity in the definitions of antibiotic exposure, cases, and controls, impacting the interpretability of their results. Moreover, only a minority used uninfected controls, although these are essential to approach the source population of the infection and thus have a global view of the role of antibiotics on the occurrence of a resistant infection. In addition to the recommendations of previous methodological reviews, we encourage the authors of future studies to extend further and clearly define a pathophysiological hypothesis specific to the bacteria-resistance pair of interest. This preliminary step would help them to design their study, according to the specific question addressed. Even though an optimal design may be unrealistic, the pathophysiological hypotheses would provide a framework for discussing the pitfalls of the achieved design and comparing the study results with those of other studies. 


\begin{abstract}
Supplementary Materials: The following supporting information can be downloaded at: https: / / www.mdpi.com/article/10.3390/antibiotics11020201/s1. Table S1: Case-control studies assessing risk factors of resistance in community-onset or community-acquired bloodstream infections and urinary tract infections; Table S2: Classifications, windows of exposure and collections of antibiotic use in case-control studies assessing risk factors of resistance in community-onset or community-acquired bloodstream infections and urinary tract infections; Table S3: Definitions of community-onset and community-acquired infections in case-control studies assessing risk factors of resistance in bloodstream infections and urinary tract infections; Table S4: Main results of case-control studies assessing antibiotic use as a risk factor of resistance in CO-BSI or CA-BSI to ESBL-producing Enterobacteriaceae, as a function of the control group; Table S5: Main results of case-control studies assessing antibiotic use as a risk factor of resistance in CO-UTI or CA-UTI to ESBL-producing Enterobacteriaceae, as a function of the control group.
\end{abstract}

Author Contributions: Conceptualization and methodology, S.A., C.B.-B., D.G., and L.W.; literature review and writing — original draft preparation, S.A.; writing-review and editing, S.A., C.B.-B., D.G., and L.W. All authors have read and agreed to the published version of the manuscript.

Funding: Funding was received from the Ecole des Hautes Etudes en Santé Publique (EHESP, https: / / www.ehesp.fr/ (accessed date 4 January 2022)) to S.A.

Conflicts of Interest: Funding received by S.A. had no role in the design of the study; in the collection, analyses, or interpretation of data; in the writing of the manuscript, or in the decision to publish the results. L.W. has received consulting fees from IQVIA and Pfizer for works outside the submitted work. The other authors declare no conflict of interest.

\title{
References
}

1. World Health Organization (WHO). Global Action Plan on Antimicrobial Resistance; WHO: Geneva, Switzerland, 2015.

2. Costelloe, C.; Metcalfe, C.; Lovering, A.; Mant, D.; Hay, A.D. Effect of Antibiotic Prescribing in Primary Care on Antimicrobial Resistance in Individual Patients: Systematic Review and Meta-Analysis. BMJ 2010, 340, c2096. [CrossRef] [PubMed]

3. The European Commission (EC). A European One Health Action Plan against Antimicrobial Resistance (AMR); EC: Brussels, Belgium, 2017.

4. Harbarth, S.; Balkhy, H.H.; Goossens, H.; Jarlier, V.; Kluytmans, J.; Laxminarayan, R.; Saam, M.; Van Belkum, A.; Pittet, D. Antimicrobial Resistance: One World, One Fight! Antimicrob. Resist. Infect. Control 2015, 4, 49. [CrossRef]

5. Nicolas-Chanoine, M.-H.; Gruson, C.; Bialek-Davenet, S.; Bertrand, X.; Thomas-Jean, F.; Bert, F.; Moyat, M.; Meiller, E.; Marcon, E.; Danchin, N.; et al. 10-Fold Increase (2006-11) in the Rate of Healthy Subjects with Extended-Spectrum -Lactamase-Producing Escherichia Coli Faecal Carriage in a Parisian Check-up Centre. J. Antimicrob. Chemother. 2013, 68, 562-568. [CrossRef]

6. Glaser, P.; Martins-Simões, P.; Villain, A.; Barbier, M.; Tristan, A.; Bouchier, C.; Ma, L.; Bes, M.; Laurent, F.; Guillemot, D.; et al. Demography and Intercontinental Spread of the USA300 Community-Acquired Methicillin-Resistant Staphylococcus Aureus Lineage. mBio 2016, 7, e02183-15. [CrossRef] [PubMed]

7. Olesen, S.W.; Barnett, M.L.; MacFadden, D.R.; Brownstein, J.S.; Hernández-Díaz, S.; Lipsitch, M.; Grad, Y.H. The Distribution of Antibiotic Use and Its Association with Antibiotic Resistance. eLife 2018, 7, e39435. [CrossRef] [PubMed]

8. European Centre for Disease Prevention and Control. Antimicrobial Consumption in the EU/EEA-Annual Epidemiological Report 2019; European Centre for Disease Prevention and Control: Stockholm, Sweden, 2020.

9. Lipsitch, M.; Samore, M.H. Antimicrobial Use and Antimicrobial Resistance: A Population Perspective. Emerg. Infect. Dis. 2002, 8, 347-354. [CrossRef]

10. Schechner, V.; Temkin, E.; Harbarth, S.; Carmeli, Y.; Schwaber, M.J. Epidemiological Interpretation of Studies Examining the Effect of Antibiotic Usage on Resistance. Clin. Microbiol. Rev. 2013, 26, 289-307. [CrossRef]

11. Harris, A.D.; Karchmer, T.B.; Carmeli, Y.; Samore, M.H. Methodological Principles of Case-Control Studies That Analyzed Risk Factors for Antibiotic Resistance: A Systematic Review. Clin. Infect. Dis. 2001, 32, 1055-1061. [CrossRef]

12. Harris, A.D.; Carmeli, Y.; Samore, M.H.; Kaye, K.S.; Perencevich, E. Impact of Severity of Illness Bias and Control Group Misclassification Bias in Case-Control Studies of Antimicrobial-Resistant Organisms. Infect. Control Hosp. Epidemiol. 2005, 26, 342-345. [CrossRef]

13. Harris, A.D.; Samore, M.H.; Carmeli, Y. Control Group Selection Is an Important but Neglected Issue in Studies of Antibiotic Resistance. Ann. Intern. Med. 2000, 133, 159. [CrossRef]

14. Kaye, K.S.; Harris, A.D.; Samore, M.; Carmeli, Y. The Case-Case-Control Study Design: Addressing the Limitations of Risk Factor Studies for Antimicrobial Resistance. Infect. Control Hosp. Epidemiol. 2005, 26, 346-351. [CrossRef]

15. Pirofski, L.; Casadevall, A. The Meaning of Microbial Exposure, Infection, Colonisation, and Disease in Clinical Practice. Lancet Infect. Dis. 2002, 2, 628-635. [CrossRef] 
16. Rodríguez-Baño, J.; Picón, E.; Gijón, P.; Hernández, J.R.; Ruíz, M.; Peña, C.; Almela, M.; Almirante, B.; Grill, F.; Colomina, J.; et al. Community-Onset Bacteremia Due to Extended-Spectrum B-Lactamase-Producing Escherichia Coli: Risk Factors and Prognosis. Clin. Infect. Dis. 2010, 50, 40-48. [CrossRef] [PubMed]

17. Hsieh, C.-J.; Shen, Y.-H.; Hwang, K.-P. Clinical Implications, Risk Factors and Mortality Following Community-Onset Bacteremia Caused by Extended-Spectrum $\beta$-Lactamase (ESBL) and Non-ESBL Producing Escherichia Coli. J. Microbiol. Immunol. Infect. 2010, 43, 240-248. [CrossRef]

18. Park, S.H.; Choi, S.-M.; Lee, D.-G.; Kim, J.; Choi, J.-H.; Kim, S.-H.; Kwon, J.-C.; Yoo, J.-H. Emergence of Extended-Spectrum $\beta$-Lactamase-Producing Escherichia Coli as a Cause of Community-Onset Bacteremia in South Korea: Risk Factors and Clinical Outcomes. Microb. Drug Resist. 2011, 17, 537-544. [CrossRef]

19. Park, Y.S.; Bae, I.K.; Kim, J.; Jeong, S.H.; Hwang, S.; Seo, Y.-H.; Cho, Y.K.; Lee, K.; Kim, J.M. Risk Factors and Molecular Epidemiology of Community-Onset Extended-Spectrum $\beta$-Lactamase-Producing Escherichia Coli Bacteremia. Yonsei Med. J. 2014, 55, 467-475. [CrossRef] [PubMed]

20. Kim, M.; Song, K.-H.; Kim, C.-J.; Choe, P.G.; Park, W.B.; Bang, J.H.; Kim, E.S.; Park, S.-W.; Kim, N.J.; Oh, M.; et al. Clinical Prediction Score for Community-Onset Bloodstream Infections Caused by Extended-Spectrum Beta-Lactamase-Producing Escherichia Coli and Klebsiella Species. J. Korean Med. Sci. 2019, 34, e116. [CrossRef] [PubMed]

21. Lee, C.-H.; Chu, F.-Y.; Hsieh, C.-C.; Hong, M.-Y.; Chi, C.-H.; Ko, W.-C.; Lee, C.-C. A Simple Scoring Algorithm Predicting Extended-Spectrum $\beta$-Lactamase Producers in Adults with Community-Onset Monomicrobial Enterobacteriaceae Bacteremia: Matters of Frequent Emergency Department Users. Medicine 2017, 96, e6648. [CrossRef]

22. Zahar, J.-R.; Lesprit, P.; Ruckly, S.; Eden, A.; Hikombo, H.; Bernard, L.; Harbarth, S.; Timsit, J.-F.; Brun-Buisson, C.; Aissa, N.; et al Predominance of Healthcare-Associated Cases among Episodes of Community-Onset Bacteraemia Due to Extended-Spectrum $\beta$-Lactamase-Producing Enterobacteriaceae. Int. J. Antimicrob. Agents 2017, 49, 67-73. [CrossRef]

23. Lin, W.-P.; Huang, Y.-S.; Wang, J.-T.; Chen, Y.-C.; Chang, S.-C. Prevalence of and Risk Factor for Community-Onset ThirdGeneration Cephalosporin-Resistant Escherichia Coli Bacteremia at a Medical Center in Taiwan. BMC Infect. Dis. 2019, 19, 245. [CrossRef] [PubMed]

24. Lee, S.; Han, S.W.; Kim, K.W.; Song, D.Y.; Kwon, K.T. Third-Generation Cephalosporin Resistance of Community-Onset Escherichia Coli and Klebsiella Pneumoniae Bacteremia in a Secondary Hospital. Korean J. Intern. Med. 2014, 29, 3932395. [CrossRef]

25. Sung, Y.K.; Lee, J.K.; Lee, K.H.; Lee, K.T.; Kang, C.-I. The Clinical Epidemiology and Outcomes of Bacteremic Biliary Tract Infections Caused by Antimicrobial-Resistant Pathogens. Am. J. Gastroenterol. 2012, 107, 473-483. [CrossRef]

26. Gottesman, B.-S.; Shitrit, P.; Katzir, M.; Chowers, M. Antibiotic Exposure in the Community and Resistance Patterns of Escherichia Coli Community-Acquired Bloodstream Infection. Isr. Med. Assoc. J. 2018, 20, 382-384. [PubMed]

27. Pedersen, G.; Schønheyder, H.C.; Steffensen, F.H.; Sørenson, H.T. Risk of Resistance Related to Antibiotic Use before Admission in Patients with Community-Acquired Bacteraemia. J. Antimicrob. Chemother. 1999, 43, 119-126. [CrossRef] [PubMed]

28. Ortega, M.; Soriano, A.; Marco, F.; Almela, M.; Martínez, J.A.; Morata, L.; Cobos-Trigueros, N.; de la Calle, C.; Mensa, J. Risk Factors for the Isolation of a Third Generation Cephalosporin Resistant Strain in Patients with Community-Acquired Enterobacteriaceae Bacteraemia. J. Infect. 2016, 72, 268-271. [CrossRef]

29. Wi, Y.M.; Rhee, J.Y.; Kang, C.I.; Chung, D.R.; Song, J.H.; Peck, K.R. Clinical Predictors of Methicillin-Resistance and Their Impact on Mortality Associated with Staphylococcus Aureus Bacteraemia. Epidemiol. Infect. 2018, 146, 1326-1336. [CrossRef] [PubMed]

30. Lim, C.J.; Cheng, A.C.; Kong, D.C.M.; Peleg, A.Y. Community-Onset Bloodstream Infection with Multidrug-Resistant Organisms: A Matched Case-Control Study. BMC Infect. Dis. 2014, 14, 126. [CrossRef] [PubMed]

31. Fan, N.-C.; Chen, H.-H.; Chen, C.-L.; Ou, L.-S.; Lin, T.-Y.; Tsai, M.-H.; Chiu, C.-H. Rise of Community-Onset Urinary Tract Infection Caused by Extended-Spectrum $\beta$-Lactamase-Producing Escherichia Coli in Children. J. Microbiol. Immunol. Infect. 2014, 47, 399-405. [CrossRef]

32. Pérez Heras, I.; Sanchez-Gomez, J.C.; Beneyto-Martin, P.; Ruano-de-Pablo, L.; Losada-Pinedo, B. Community-Onset ExtendedSpectrum $\beta$-Lactamase Producing Escherichia Coli in Urinary Tract Infections in Children from 2015 to 2016: Prevalence, Risk Factors, and Resistances. Medicine 2017, 96, e8571. [CrossRef]

33. Søgaard, M.; Heide-Jørgensen, U.; Vandenbroucke, J.P.; Schønheyder, H.C.; Vandenbroucke-Grauls, C.M.J.E. Risk Factors for Extended-Spectrum $\beta$-Lactamase-Producing Escherichia Coli Urinary Tract Infection in the Community in Denmark: A Case-Control Study. Clin. Microbiol. Infect. 2017, 23, 952-960. [CrossRef]

34. Tüzün, T.; Sayın Kutlu, S.; Kutlu, M.; Kaleli, İ. Risk Factors for Community-Onset Urinary Tract Infections Caused by ExtendedSpectrum $\beta$-Lactamase-Producing Escherichia Coli. Turk. J. Med. Sci. 2019, 49, 1206-1211. [CrossRef] [PubMed]

35. Boix-Palop, L.; Xercavins, M.; Badía, C.; Obradors, M.; Riera, M.; Freixas, N.; Pérez, J.; Rodríguez-Carballeira, M.; Garau, J.; Calbo, E. Emerging Extended-Spectrum $\beta$-Lactamase-Producing Klebsiella Pneumoniae Causing Community-Onset Urinary Tract Infections: A Case-Control-Control Study. Int. J. Antimicrob. Agents 2017, 50, 197-202. [CrossRef] [PubMed]

36. Kung, C.-H.; Ku, W.-W.; Lee, C.-H.; Fung, C.-P.; Kuo, S.-C.; Chen, T.-L.; Lee, Y.-T. Epidemiology and Risk Factors of CommunityOnset Urinary Tract Infection Caused by Extended-Spectrum $\beta$-Lactamase-Producing Enterobacteriaceae in a Medical Center in Taiwan: A Prospective Cohort Study. J. Microbiol. Immunol. Infect. 2015, 48, 168-174. [CrossRef]

37. Calbo, E.; Romaní, V.; Xercavins, M.; Gómez, L.; Vidal, C.G.; Quintana, S.; Vila, J.; Garau, J. Risk Factors for Community-Onset Urinary Tract Infections Due to Escherichia Coli Harbouring Extended-Spectrum $\beta$-Lactamases. J. Antimicrob. Chemother. 2006, 57, 780-783. [CrossRef] [PubMed] 
38. Zhu, F.H.; Rodado, M.P.; Asmar, B.I.; Salimnia, H.; Thomas, R.; Abdel-Haq, N. Risk Factors for Community Acquired Urinary Tract Infections Caused by Extended Spectrum $\beta$-Lactamase (ESBL) Producing Escherichia Coli in Children: A Case Control Study. Infect. Dis. 2019, 51, 802-809. [CrossRef]

39. Topaloglu, R.; Er, I.; Dogan, B.G.; Bilginer, Y.; Ozaltin, F.; Besbas, N.; Ozen, S.; Bakkaloglu, A.; Gur, D. Risk Factors in CommunityAcquired Urinary Tract Infections Caused by ESBL-Producing Bacteria in Children. Pediatr. Nephrol. 2010, 25, 919-925. [CrossRef]

40. Yilmaz, E.; Akalin, H.; Özbey, S.; Kordan, Y.; Sinirtaş, M.; Gürcüoglu, E.; Özakin, C.; Heper, Y.; Mistik, R.; Helvaci, S. Risk Factors in Community-Acquired/Onset Urinary Tract Infections Due to Extended-Spectrum Beta-Lactamase-Producing Escherichia Coli and Klebsiella Pneumoniae. J. Chemother. 2008, 20, 581-585. [CrossRef]

41. Colodner, R.; Rock, W.; Chazan, B.; Keller, N.; Guy, N.; Sakran, W.; Raz, R. Risk Factors for the Development of Extended-Spectrum Beta-Lactamase-Producing Bacteria in Nonhospitalized Patients. Eur. J. Clin. Microbiol. Infect. Dis. 2004, 23, 163-167. [CrossRef]

42. Albaramki, J.H.; Abdelghani, T.; Dalaeen, A.; Khdair Ahmad, F.; Alassaf, A.; Odeh, R.; Akl, K. Urinary Tract Infection Caused by Extended-spectrum B-lactamase-producing Bacteria: Risk Factors and Antibiotic Resistance. Pediatr. Int. 2019, 61, 1127-1132. [CrossRef]

43. Guzmán, M.; Salazar, E.; Cordero, V.; Castro, A.; Villanueva, A.; Rodulfo, H.; De Donato, M. Multidrug Resistance and Risk Factors Associated with Community-Acquired Urinary Tract Infections Caused by Escherichia Coli in Venezuela. Biomedica 2019, 39, 96-107. [CrossRef]

44. Koksal, E.; Tulek, N.; Sonmezer, M.C.; Temocin, F.; Bulut, C.; Hatipoglu, C.; Erdinc, F.S.; Ertem, G. Investigation of Risk Factors for Community-Acquired Urinary Tract Infections Caused by Extended-Spectrum Beta-Lactamase Escherichia Coli and Klebsiella Species. Investig. Clin. Urol. 2019, 60, 46. [CrossRef]

45. Azap, Ö.K.; Arslan, H.; Şerefhanoğlu, K.; Çolakoğlu, Ş.; Erdoğan, H.; Timurkaynak, F.; Senger, S.S. Risk Factors for ExtendedSpectrum $\beta$-Lactamase Positivity in Uropathogenic Escherichia Coli Isolated from Community-Acquired Urinary Tract Infections. Clin. Microbiol. Infect. 2010, 16, 147-151. [CrossRef] [PubMed]

46. Rodríguez-Baño, J.; Alcalá, J.C.; Cisneros, J.M.; Grill, F.; Oliver, A.; Horcajada, J.P.; Tórtola, T.; Mirelis, B.; Navarro, G.; Cuenca, M.; et al. Community Infections Caused by Extended-Spectrum $\beta$-Lactamase-Producing Escherichia Coli. Arch. Intern. Med. 2008, 168, 1897. [CrossRef] [PubMed]

47. Castillo-Tokumori, F.; Irey-Salgado, C.; Málaga, G. Worrisome High Frequency of Extended-Spectrum Beta-Lactamase-Producing Escherichia Coli in Community-Acquired Urinary Tract Infections: A Case-Control Study. Int. J. Infect. Dis. 2017, 55, 16-19. [CrossRef] [PubMed]

48. Megged, O. Extended-Spectrum $\beta$-Lactamase-Producing Bacteria Causing Community-Acquired Urinary Tract Infections in Children. Pediatr. Nephrol. 2014, 29, 1583-1587. [CrossRef] [PubMed]

49. Chervet, D.; Lortholary, O.; Zahar, J.-R.; Dufougeray, A.; Pilmis, B.; Partouche, H. Antimicrobial Resistance in CommunityAcquired Urinary Tract Infections in Paris in 2015. Méd. Mal. Infect. 2018, 48, 188-192. [CrossRef]

50. Jacmel, L.; Timsit, S.; Ferroni, A.; Auregan, C.; Angoulvant, F.; Chéron, G. Extended-Spectrum $\beta$-Lactamase-Producing Bacteria Caused Less than 5\% of Urinary Tract Infections in a Paediatric Emergency Centre. Acta Paediatr. 2017, 106, 142-147. [CrossRef]

51. Brosh-Nissimov, T.; Navon-Venezia, S.; Keller, N.; Amit, S. Risk Analysis of Antimicrobial Resistance in Outpatient Urinary Tract Infections of Young Healthy Adults. J. Antimicrob. Chemother. 2019, 74, 499-502. [CrossRef]

52. Colodner, R.; Kometiani, I.; Chazan, B.; Raz, R. Risk Factors for Community-Acquired Urinary Tract Infection Due to QuinoloneResistant E. Coli. Infection 2008, 36, 41-45. [CrossRef]

53. Seija, V.; Fratchez, V.; Ventura, V.; Pintos, M.; González, M. Risk factors for community-acquired urinary tract infection caused by fluoroquinolone resistant E. coli. Rev. Chil. Infectol. 2014, 31, 400-405. [CrossRef]

54. Killgore, K.M.; March, K.L.; Guglielmo, B.J. Risk Factors for Community-Acquired Ciprofloxacin-Resistant Escherichia Coli Urinary Tract Infection. Ann. Pharmacother. 2004, 38, 1148-1152. [CrossRef]

55. Chaniotaki, S.; Giakouppi, P.; Tzouvelekis, L.S.; Panagiotakos, D.; Kozanitou, M.; Petrikkos, G.; Avlami, A.; Vatopoulos, A.C. Quinolone Resistance among Escherichia Coli Strains from Community-Acquired Urinary Tract Infections in Greece. Clin. Microbiol. Infect. 2004, 10, 75-78. [CrossRef]

56. Dromigny, J.A.; Nabeth, P.; Juergens-Behr, A.; Perrier-Gros-Claude, J.D. Risk Factors for Antibiotic-Resistant Escherichia Coli Isolated from Community-Acquired Urinary Tract Infections in Dakar, Senegal. J. Antimicrob. Chemother. 2005, 56, 236-239. [CrossRef] [PubMed]

57. Hillier, S.; Roberts, Z.; Dunstan, F.; Butler, C.; Howard, A.; Palmer, S. Prior Antibiotics and Risk of Antibiotic-Resistant CommunityAcquired Urinary Tract Infection: A Case-Control Study. J. Antimicrob. Chemother. 2007, 60, 92-99. [CrossRef] [PubMed]

58. Anesi, J.A.; Lautenbach, E.; Nachamkin, I.; Garrigan, C.; Bilker, W.B.; Wheeler, M.; Tolomeo, P.; Han, J.H. Clinical and Molecular Characterization of Community-Onset Urinary Tract Infections Due to Extended-Spectrum Cephalosporin-Resistant Enterobacteriaceae. Infect. Control Hosp. Epidemiol. 2016, 37, 1433-1439. [CrossRef] [PubMed]

59. Lee, C.-H.; Lee, Y.-T.; Kung, C.-H.; Ku, W.-W.; Kuo, S.-C.; Chen, T.-L.; Fung, C.-P. Risk Factors of Community-Onset Urinary Tract Infections Caused by Plasmid-Mediated AmpC $\beta$-Lactamase-Producing Enterobacteriaceae. J. Microbiol. Immunol. Infect. 2015, 48, 269-275. [CrossRef]

60. Smithson, A.; Chico, C.; Ramos, J.; Netto, C.; Sanchez, M.; Ruiz, J.; Porron, R.; Bastida, M.T. Prevalence and Risk Factors for Quinolone Resistance among Escherichia Coli Strains Isolated from Males with Community Febrile Urinary Tract Infection. Eur. J. Clin. Microbiol. Infect. Dis. 2012, 31, 423-430. [CrossRef] 
61. Bosch-Nicolau, P.; Falcó, V.; Viñado, B.; Andreu, A.; Len, O.; Almirante, B.; Pigrau, C. A Cohort Study of Risk Factors That Influence Empirical Treatment of Patients with Acute Pyelonephritis. Antimicrob. Agents Chemother. 2017, 61, e01317-17. [CrossRef] [PubMed]

62. Filiatrault, L.; McKay, R.M.; Patrick, D.M.; Roscoe, D.L.; Quan, G.; Brubacher, J.; Collins, K.M. Antibiotic Resistance in Isolates Recovered from Women with Community-Acquired Urinary Tract Infections Presenting to a Tertiary Care Emergency Department. Can. J. Emerg. Med. 2012, 14, 295-305. [CrossRef] [PubMed]

63. Ruppé, E.; Andremont, A. Causes, Consequences, and Perspectives in the Variations of Intestinal Density of Colonization of Multidrug-Resistant Enterobacteria. Front. Microbiol. 2013, 4, 129. [CrossRef]

64. Pilmis, B.; Le Monnier, A.; Zahar, J.-R. Gut Microbiota, Antibiotic Therapy and Antimicrobial Resistance: A Narrative Review. Microorganisms 2020, 8, 269. [CrossRef]

65. Ruppé, E.; Armand-Lefèvre, L.; Estellat, C.; Consigny, P.-H.; El Mniai, A.; Boussadia, Y.; Goujon, C.; Ralaimazava, P.; Campa, P.; Girard, P.-M.; et al. High Rate of Acquisition but Short Duration of Carriage of Multidrug-Resistant Enterobacteriaceae After Travel to the Tropics. Clin. Infect. Dis. 2015, 61, 593-600. [CrossRef]

66. Titelman, E.; Hasan, C.M.; Iversen, A.; Nauclér, P.; Kais, M.; Kalin, M.; Giske, C.G. Faecal Carriage of Extended-Spectrum $\beta$-Lactamase-Producing Enterobacteriaceae Is Common 12 Months after Infection and Is Related to Strain Factors. Clin. Microbiol. Infect. 2014, 20, O508-O515. [CrossRef] [PubMed]

67. Friedman, N.D.; Kaye, K.S.; Stout, J.E.; McGarry, S.A.; Trivette, S.L.; Briggs, J.P.; Lamm, W.; Clark, C.; MacFarquhar, J.; Walton, A.L.; et al. Health Care-Associated Bloodstream Infections in Adults: A Reason to Change the Accepted Definition of CommunityAcquired Infections. Ann. Intern. Med. 2002, 137, 791-797. [CrossRef]

68. Kollef, M.H.; Shorr, A.; Tabak, Y.P.; Gupta, V.; Liu, L.Z.; Johannes, R.S. Epidemiology and Outcomes of Health-Care-Associated Pneumonia: Results from a Large US Database of Culture-Positive Pneumonia. Chest 2005, 128, 3854-3862. [CrossRef] [PubMed]

69. Ewig, S.; Welte, T.; Chastre, J.; Torres, A. Rethinking the Concepts of Community-Acquired and Health-Care-Associated Pneumonia. Lancet Infect. Dis. 2010, 10, 279-287. [CrossRef]

70. European Centre for Disease Prevention and Control. Point Prevalence Survey of Healthcare-Associated Infections and Antimicrobial Use in European Acute Care Hospitals 2011-2012; European Centre for Disease Prevention and Control: Stockholm, Sweden, 2013.

71. Angebault, C.; Andremont, A. Antimicrobial Agent Exposure and the Emergence and Spread of Resistant Microorganisms: Issues Associated with Study Design. Eur. J. Clin. Microbiol Infect. Dis. 2013, 32, 581-595. [CrossRef]

72. Whitmer, G.R.; Moorthy, G.; Arshad, M. The Pandemic Escherichia Coli Sequence Type 131 Strain Is Acquired Even in the Absence of Antibiotic Exposure. PLoS Pathog. 2019, 15, e1008162. [CrossRef]

73. Morales Barroso, I.; López-Cerero, L.; Navarro, M.D.; Gutiérrez-Gutiérrez, B.; Pascual, A.; Rodríguez-Baño, J. Intestinal Colonization Due to Escherichia Coli ST131: Risk Factors and Prevalence. Antimicrob. Resist. Infect. Control 2018, 7, 135. [CrossRef]

74. Prevel, R.; Boyer, A.; M'Zali, F.; Lasheras, A.; Zahar, J.-R.; Rogues, A.-M.; Gruson, D. Is Systematic Fecal Carriage Screening of Extended-Spectrum Beta-Lactamase-Producing Enterobacteriaceae Still Useful in Intensive Care Unit: A Systematic Review. Crit. Care 2019, 23, 170. [CrossRef] [PubMed]

75. Goulenok, T.; Ferroni, A.; Bille, E.; Lécuyer, H.; Join-Lambert, O.; Descamps, P.; Nassif, X.; Zahar, J.-R. Risk Factors for Developing ESBL E. Coli: Can Clinicians Predict Infection in Patients with Prior Colonization? J. Hosp. Infect. 2013, 84, 294-299. [CrossRef] [PubMed]

76. Razazi, K.; Rosman, J.; Phan, A.-D.; Carteaux, G.; Decousser, J.-W.; Woerther, P.L.; de Prost, N.; Brun-Buisson, C.; Mekontso Dessap, A. Quantifying Risk of Disease Due to Extended-Spectrum $\beta$-Lactamase Producing Enterobacteriaceae in Patients Who Are Colonized at ICU Admission. J. Infect. 2020, 80, 504-510. [CrossRef] [PubMed]

77. Rottier, W.C.; Bamberg, Y.R.P.; Dorigo-Zetsma, J.W.; van der Linden, P.D.; Ammerlaan, H.S.M.; Bonten, M.J.M. Predictive Value of Prior Colonization and Antibiotic Use for Third-Generation Cephalosporin-Resistant Enterobacteriaceae Bacteremia in Patients with Sepsis. Clin. Infect. Dis. 2015, 60, 1622-1630. [CrossRef]

78. Vodovar, D.; Marcadé, G.; Rousseau, H.; Raskine, L.; Vicaut, E.; Deye, N.; Baud, F.J.; Mégarbane, B. Predictive Factors for Extended-Spectrum Beta-Lactamase Producing Enterobacteriaceae Causing Infection among Intensive Care Unit Patients with Prior Colonization. Infection 2014, 42, 743-748. [CrossRef]

79. Cho, S.Y.; Kang, C.-I.; Cha, M.K.; Wi, Y.M.; Ha, Y.E.; Chung, D.R.; Lee, N.Y.; Peck, K.R.; Song, J.-H.; on behalf of the Korean Network for Study on Infectious Diseases (KONSID). Clinical Features and Treatment Outcomes of Bloodstream Infections Caused by Extended-Spectrum $\beta$-Lactamase-Producing Escherichia Coli Sequence Type 131. Microb. Drug Resist. 2015, 21, 463-469. [CrossRef] [PubMed]

80. Kim, H.; Kim, Y.A.; Park, Y.S.; Choi, M.H.; Lee, G.I.; Lee, K. Risk Factors and Molecular Features of Sequence Type (ST) 131 Extended-Spectrum $\beta$-Lactamase-Producing Escherichia Coli in Community-Onset Bacteremia. Sci. Rep. 2017, 7, 14640. [CrossRef] [PubMed]

81. Bardini, R.; Di Carlo, S.; Politano, G.; Benso, A. Modeling Antibiotic Resistance in the Microbiota Using Multi-Level Petri Nets. BMC Syst. Biol. 2018, 12, 108. [CrossRef]

82. Knight, G.M.; Davies, N.G.; Colijn, C.; Coll, F.; Donker, T.; Gifford, D.R.; Glover, R.E.; Jit, M.; Klemm, E.; Lehtinen, S.; et al. Mathematical Modelling for Antibiotic Resistance Control Policy: Do We Know Enough? BMC Infect. Dis. 2019, $19,1011$. [CrossRef] 